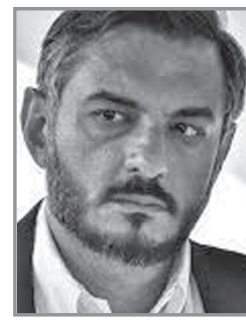

МИомир ПЕТРОВИЋ

Институт за уметничку игру

Београд

УДК: 82.0-2(4)»18»

КОНТАКТ: miomir.petrovic@iui.rs

ПРИМЉЕН: 16. 11. 2021.

ПРИХВАЋЕН: 1. 12. 2021. $\$

\title{
TЕОРИЈА ФРАЈТАГОВЕ
}

ПИРАМИДЕ И ЊЕНА

ПРИМЕНЉИВОСТ

\section{HA CABPEMEHO \\ НАРАТИВНО ДЕЛО}

Апстракт: Током 19. века, до песника/писаца тог доба долази теорија немачког драматичара Густава Фрајтага (1816-1895). Иако је ова теорија писана реалтивно давно, те можемо рећи да је то теорија одређених конвенција које су, наизглед, превазиђене, као и то и репрезентује извесну полемику (или пре реперкусију, последицу) у односу на већ помињано Аристотелово дело... чини се да да дана данашњег она није изгубила на својој актуелности. Наравно, у својој теорији „Драма - Техника писања”, Густав Фрајтаг првенствено у мисли на писање драма, али, након чак и површне анализе лако долазимо до закључка да је такозвана Фрајтагова пирамида (структурална схема) применљива (приметили бисмо, више него икада) на писање било ког наративног, дакле приповедалачког дела и итекако важна за савремено тумачење креативног писања. Густав Фрајтаг полази од једноставног закључка - свака прича нужно поседује свој Раст, Преокрет и свој Пад (у односу на Жељено добро). Да ли ће се из тог пада главни ликови (носиоци протагоне радње) „извући” зависи, по Фрајтагу, од жанра једног дела. У модерном тумачењу зависи од ауторске итендације (списатељске намере). Односно, шта то, по писцу, протагонисти „треба да добију или освоје" а шта не. Управо у његовом тумачењу раста, развоја и преокрета у причи - Аристотел би рекао перипетији - можемо уочити савременост у размишљању једног класичног теоретичара. Уколико се амбициозније приступи Фрајтаговом тумачењу композиције дела, брзо уочавамо да не постоји савремено (модерно) испричана прича (и то у било којој медији: роману, драми, филмском или телевизијском сценарију) која, у већој или мањој мери, не подлеже наизглед једноставним законитостима које нам препоручује овај теоретичар.

КљУчне речи: КРЕАТИВНО ПИСАҢЕ, ПОЗОРИШТЕ, МИТ, ДРАМА, ЛИК, ДИЈАЛОГ, АНТАГОНО, ПРОТАГОНО. 


\section{Пирамидална нарација}

Попут Аристотела, Густав Фрајтаг не производи својом „пирамидом” ефекат новог манифеста, изма, упутства како савремено дело треба да изгледа већ, једноставно, констатује да је већина приповедалачких ремек-дела написана у кључу који он, као теоретичар идентификује (препознаје). Ово је важна напомена, јер се мора схватити да нису сви теоретичари књижевности нужно желели да инаугуришу одређени став (да створе некакав манифест), него да су најбољи од њих, рекли би, једноставно анализирали дела која су сматрали „великим, и покушавали да из њих извуку есенцију композиције.

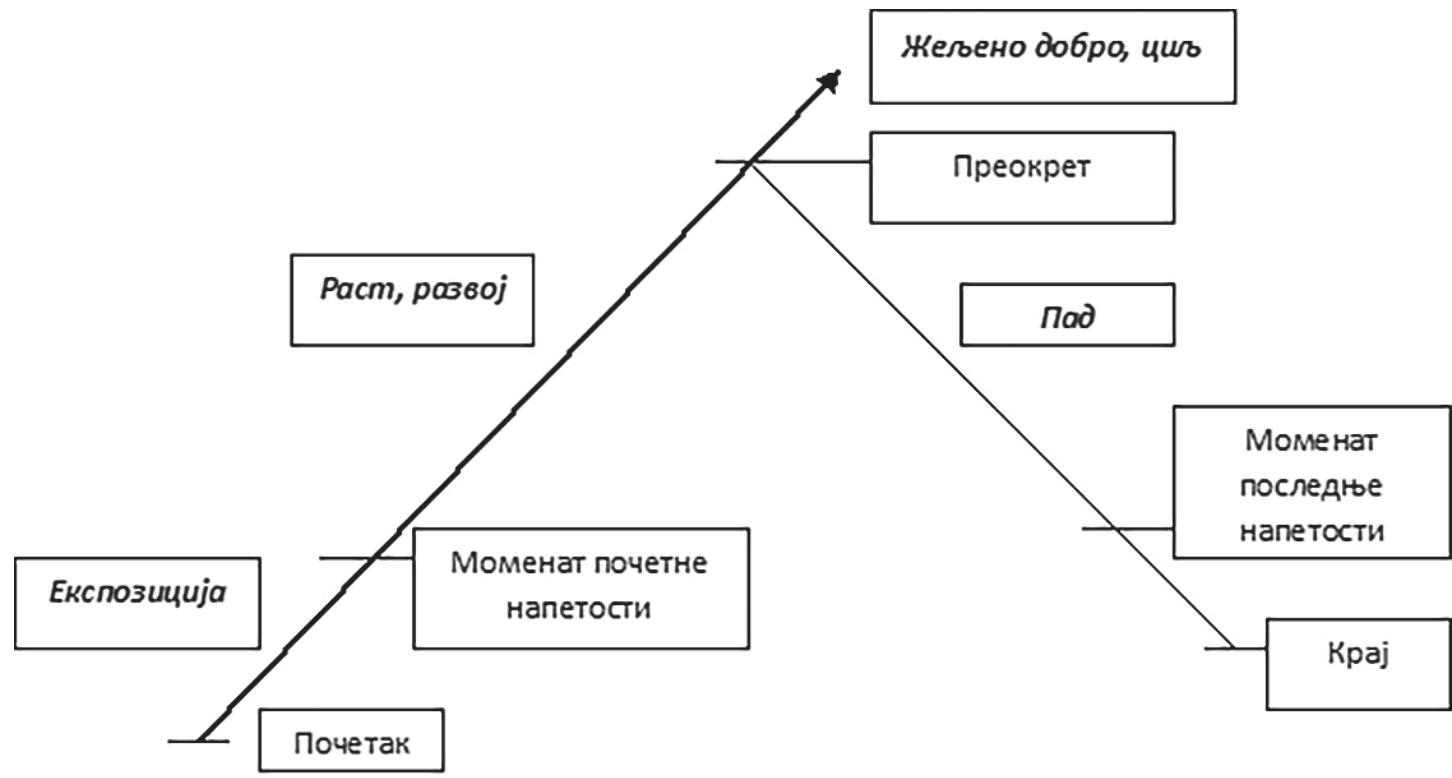

Схема 1: Фрајтагова пирамида

Из ове схеме произилази да свако наративно дело, без обзира у којој медији је написана, да свака прича, дакле, поседује свој Успон и свој Пад (у односу на Жељено добро). Другим речима, протагониста/е жели/е нешто (Жељено добро) и чини/е све да достигне/у тај Циљ. Свака прича има свој Почетак и, по Фрајтагу (Freytag, 2000), све до Момента почетне напетости (када се дешава нешто драматично, нешто што ће протагонисту/е узбудити или збунити, а с њим/а и рецепцијенте, читаоце) одвија се Експозиција, односно Увод у радњу. 


\section{МИомир ПЕТРОВИЋ}

Институт за уметничку игру

Након Момента почетне напетости протагониста/е ће покушати да се прилагоди/е новонасталим односима који га/их удаљује од Жељеног добра. Другим речима, почеће Раст или Развој приче.

Прича, базично, говори о томе која ће нова средства протагониста/е уложити у постизање (достизање) Жељеног добра. Таман када је/су протагониста/е близу разрешења свог проблема, достизања тог добра, долази до Преокрета (перипетије), а следствено и до Пада у односу на Жељено добро.

Пад траје све до Момента последње напетости у коме ће протагониста/е или достићи Жељено добро или ће од њега одустати (у зависности од жанра приче). Наком Момента последње напетости траје Епилог, односно приближавање Крају приче. Крај приче, такође, зависи од изабраног жанра.

Дакле, када помно размотримо ову, наизглед једноставну схему (пирамиду), доћи ћемо, као рецепцијенти, до закључка да свако приповедање карактеришу управо појмови до којих је дошао Густав Фрајтаг.

Било да се ради о Софокловом „Цару Едипу” или ТВ серији „Пријатељи”.

\section{Лик - биографија и биологија (физиологија) литерарног лика}

Иако то може зазвучати као најопштије од свих општих места, не постоји продукт креативног писања а да у његовој суштини, сржи, нема литерарног лика - особе од крви и меса. Разлог за неопходност лика, као централне тачке приповедања, једноставан је: уколико желимо да се читалац (рецепцијент) литерарног дела идентификује с делом, он то може урадити готово искључиво посредством литерарног лика. Некога ко подсећа на нас саме или се можемо, макар у одређеном смислу, поистоветити с њим. Наравно, то не значи да не постоје литерарна дела која искључују живо биће и наместо лика (од крви и меса) употребљавају продукте неживе или живе природе (дрво, трамвај, тараба...). То је нарочито било популарно у доба надреализма и дадаизма (нека дела Гијома Аполинера, на пример), који као уметнички покрети, пркосе реализму као правцу за који смо већ констатовали да чини срж сваког приповедања.

Уколико изумемо такве примере, можемо доћи до извесне схеме: читалац прати развојни пут и хитање протагонисте ка такозваном Жељеном добру (циљу) коме, на том путу, смета антагониста (односно покретач негативне радње). Од степена препознавања, односно идентификације са протагонистом (или, ванредно, антагонистом) код самог читаоца зависи да ли ће наше дело бити прихваћено или не. Ма колико академски и круто звучала оваква изјава - која као да укида нереалистички приступ у савременом приповедању - додаћемо то да се у овој студији бавимо реалистичким приповедањем. 


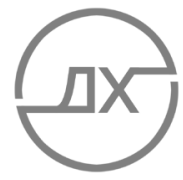

Литерарни лик, протагониста али и антагониста, морају бити уверљиви на макар два плана: на плану његове/њене биографије и плану његове/њене биологије (физиологије). Постоје писци који, пре почетка рада на рукопису, брижљиво записују биографске податке свог литерарног лика али тако да у ткиво приче (романа) уђе само 20\% података које су унапред одредили да карактеришу њихов лик. Али, у том случају, тих 20\% биографских података представљају само „врх леденог брега” који читалац региструје, док осталих 80\% остају скривени али итекако могу да се, током развоја приче, наслуте. Други писци, пак, стварају биографије својих ликова „у ходу”, односно док реализују (пишу) роман (штиво).

У биографске податке спадају најосновније, друштвено мерљиве категорије које лик чине ликом. Од године рођења преко социјалног статуса, образовања, преференција и анимозитета, начина на који говоре, начина на који се постављају у одређеним ситуацијама. Говор, односно начин на који лик вербално комуницира са својом околином, на пример, може бити реалнији податак о нечијем социјалном статусу него било какво родословно стабло. Када је неко завршио одређени факултет, како се сналази у професији коју је изабрао или која је изабрала њега/њу, када је и под каквим условима засновао/ла брачну заједницу... све су то биографски подаци који лик чине уверљивим.

С друге стране, у одређеној литерарној (драматичној, преломној) ситуацији много више има значаја - да импровизујемо - да ли је реч о факултетски образованом лику, углађеном у својим манирима и наизглед добром супружнику... непосредно пре него што ће убити своју супругу или себе (или обоје) било под утицајем кокаина или лоше домаће ракије, него што је то његов/њен датум рођења или дипломирања на, на пример, Грађевинском факултету.

Тада већ задиремо, као аутори и као читаоци, у његову биологију, односно физиологију, будући да је неубедљиво приказати - на пример - спортског аса који је често под утицајем алкохола, или ноторног алкохоличара који сваког јутра џогира пет километара. Напросто, биологија (физиологија) лика се, у том случају, не уклапа у његову биографију и читаоци, будући неспремни на такав обрт, бивају изненађени и, више од тога, уверени како је то што се догодило напросто неуверљиво. Да ли је лик физички упадљиво леп/а или непривлачан/ на није ствар биографије лика већ пре његове биологије (физиологије) а то итекако може имати утицаја на догађаје у причи.

У свом драматуршком приручнику „Написати сценарио”, француски теоретичар примењене драматургије Мишел Шион пише:

„Синди Филд (теоретичар филма, прим. М. П.) дефинише лик у три равни: у професионалној равни (а то је полазна тачка карактеризације, каже он, што је можда типична америчка примедба), у личној равни (породица и пријатељи личности) и у интимној равни. Филд додаје: Лик је основа сценарија, и ви је морате добро упознати пре него што напишете прву реч текста... Филд раздваја оно што лик карактерише од његовог рођења до почетка радње и што се 


\section{МИомир ПЕТРОВИЋ}

Институт за уметничку игру

назива његовом унутрашношћу од онога што се у том лику разоткрива током збивања, од почетка до завршетка приче, и што се назива његовом спољашношћу - формулација је можда спорна, али уочена разлика није без значаја...

По мишљењу неких зналаца, постоји дихотонија (разлика, контрадикторност, прим. М. П.) између акције и карактера, између перипетије (обрта) и психолошког богатства лика... Аристотел у Арс Поетици каже: Људи су овакви или онакви због свог карактера (дословно: та етхе - своје нарави); а срећни су или несрећни због свог делања. Ликови, дакле, не делају зато да би одразили овакав или онакав карактер, они карактер добијају кроз своје делање." (Шион, 1989: 91-92)

Другим речима, квалитетно формиран литерарни лик се доказује (процесуира) током збивања својим делањем у литерарном делу а не пуким биографским подацима. Један од оснивача структуралистичке мисли, Ролан Барт тврди:

„У Аристотелој Арс Поетици, појам лика је од споредног значаја и потпуно је подређен појму делања: постоје приче без карактера, али не постоје карактери без приче, каже Аристотел. Лик који је једно време био само име, носилац радње, неко ко добија касније психолошку чврстину, постаје јединка, неко, речју једно целовито биће, чак и онда када баш ништа није урадило и, наравно, пре него што је било шта започело." (Барт, 1979)

То нас доводи до немогућности да се, у једном литерарном делу, раздвоје биографија и биологија лика, дакле лик од свог делања, односно онога што доказују током развоја приче. Самим тим, мотивација, односно мотивациони склоп литерарног јунака постају неизбежна тема, процесуализација самог лика који мора нешто да ради, потврђује или оповргава да би уопште деловао на читаоца као формиран лик. Поново ћемо консултовати Аристотела који, када је реч о трагичком јунаку пише:

„...Ни честити људи не треба пред нашим очима да доживљавају пад из несреће у срећу - јер то не би изазвало ни страха ни сажаљења, него гнушање; затим ни рђави из несреће у срећу (јер то би највише било противно задатку трагедије)... Најзад, ни веома рђав човек не сме из среће да се строваљује у несрећу. Такав склоп изазвао би, додуше, осећање човештва, али не би изазва ни сажаљења ни страха, јер сажаљење изазива само онај ко незаслужено пати а страх онај који је нама самима сличан... Преостаје само један човек по средини. А такав је онај који се не истиче ни врлином ни праведношћу, нити пада у несрећу због своје злоће и свог неваљалства него због неке погрешке, а то је лице које ужива знатан углед и живи срећним животом, као Едип и Тијест." (Аристотел, 1982) 
Дакле, основа за успешан и уверљив лик литерарног дела (без обзира што Аристотел говори искључиво о трагедији) је неко ко је сличан читаоцу, с којим читалац може да се поистовети. На овом месту морамо рећи чувено поетско: „Осим ако”! Уколико је наш лик таксиста - да импровизујемо - а говори језиком нукеларног физичара, онда се шири хоризонт очекивања читаоца и поставља низ питања од којих је прво, свакако: Зашто је нуклеарни физичар постао таксиста? А можда баш у том питању лежи нуклеус, наратив радње која следи. Још Молијер каже, да га парафразирамо, да уколико је јунак недоследан, онда треба да буде доследан у својој недоследности. Литерарни ликови су, зато, први и основни link који рецепцијент успоставља у сусрету с литерарним делом.

\section{Протагоно и антагоно, мотивациони склоп у литерарном делу}

Уколико смо утврдили да читалачку пажњу заокупља потрага протагонисте за жељеним добром, а да му на том путу смета антагониста (или група протагониста против групе антагониста) већ смо дошли до процесуалности приповеданог дела. Нешто, дакле, мора одредити делање протагониста и антагониста. Самим тим, у једном делу је све што води ка бољитку, инаугурише поштење или избављење, у складу с тренутним (или општим) друштвеним начелима морала јесте такозвана протагона радња, док је све оно што стоји на путу протагоном хтењу - антигона радња.

Какав је антагониста - по својој унутарњој снази, исправности свог циља, моћима и могућностима, такав мора да буде и антагониста.

Канадски теоретичар књижевности Нортроп Фрај врши поделу ликова на високомиметске (они који су попут нас или много бољи од нас самих) и нискомиметске (оне који су гори од нас самих). Тако је и у случају протагонисте и антагонисте, односно њихове протагоне и антагоне радње. Високомиметском протагонисти пристоји само високомиметски антагониста. Противник једног Шерлока Холмса је Доктор Моријарти, и то је сасвим на месту, јер у супротном би била превише предвидива (очекивана) победа протагонисте над антагонистом.

Тако је и у случају „Илијаде”, где су Агамемнону и Менелају супротстављени Пријам а Одисеју и Ахилу - Хектор и Парис. Пре свега, у неизвесности око тога ко ће превладати аутор одржава пажњу (suspens, енг.) код читаоца. У одређеним жанровима, попут комедије и њених екстензија, природно је да актери (протагониста, антагониста и остали ликови) буду, по Фрају, нискомиметске личности и тада је антагониста, у својој снази и моћи, прилагођен протагонисти.

Међутим, прича о протагоном и антагоном нас нужно доводи до нуклеуса наратива у приповедању, а то је мотивација. Промишљена, убедљива и адекватна мотивација мора бити везана и за протагонисту и за антагонисту. Шта је мотивација? То је читав унутрашњи (психолошки) и спољашњи (околности у датом 


\section{Миомир ПЕТРОВИЋ}

Институт за уметничку игру

тренутку) склоп. Једно је - да импровизујемо - бити високи официр ЈНА у околностима 1971. године а сасвим друго бити, по професији исто то али у околностима 1995. године. Само се у умрежењу, или чешће сукобљавању унутрашњег и спољашњег фактора гради такозвани мотивациони склоп?

Шта је мотивациони склоп? То је структура, мрежа, међусобни однос унутрашњег и спољашњег који доводи до драме, до поенте нашег приповедања. Без мотивационог склопа (једно мотивише Шерлока Холмса, нешто сасвим супротно али истоветно снажно у амбицији мотивише Доктора Моријартија), не би било ни смисла приповедања у креативном писању. Дакле, можемо закључити да: од постепеног раста између хтења и моћи који ће, негде на трећини литерарног дела постати озбиљна, компликована структура - нема ни приповедања.

Зато нам је у литерарном делу, поред појединачних мотивација, чији корен лежи у индивидуалној психологији ликова, потребан и мотивациони склоп. Односно, укрштање амбиција протагоног и антагоног у правцу Жељеног добра.

Само снажно, јасно али истовремено и сложено компонован мотивациони склоп ликова доноси преко потребну драму у једном литерарном делу, односно штиво чини сложеним и управо зато пријемчивим за читаоца. Читалац увек мора да се пита шта је то што ликове мотивише да наставе даље, чак и онда када су шансе окренуте против њих, шта је то што антагонистима „не да мира” чак и када су скоро сасвим побеђени па настављају са својом контра-радњом у смислу ометања протагониста?

Да не буде забуне, то што роман - за разлику од драме или филмског и телевизијског сценарија (у којима је, по правилима драмске уметности, све саздано од делања) - може и мора да поседује многе додатне, поетске или филозофске дискурсе, као и то што у њему, као делу, не зависи „баш све” од делања ликова већ и од деспкрипције (описа), стања, филозофских дискурса... не умањује потребу да приповедање и у савременом роману буде саткано од мотивација, односно мотивационог склопа његових јунака.

\section{Дијалог}

Слично као и када говоримо о делању јунака у роману, дијалог јесте основно изражајно средство драмског приповедања али је и једно од важнјих категорија у савременом роману. То, наравно, не значи да се у читалачкој пракси не срећемо с романсијерским ремек-делима у којима нема уопште дијалога, али се тада ради о интроспективним, романима једног лика чија су унутрашња стања далеко важнија од његовог делања, односно интеракције с другим јунацима. „Смрт у Венецији" Томаса Мана, дакако, не почива на дијалогу или квалитету дијалога. Поетска проза, такође, не доказује своју аутентичност присуством дијалога. Али готово да нема савременог романа у коме, бар у малом проценту, није заступљен дијалог. Зашто је дијалог тако важна категорија? 
Пре свега зато што дијалог (али и унутрашњи монолог, говор a parte) открива мисли и стања, па чак и најинтимнија, наших ликова. Сигурно да делање открива још експлицитније оно што је наш јунак у стању да уради или ће урадити, али је дијалог оно што га „разоткрива, на прави начин, као и његове саговорнике. Многе категорије, било је већ речи о томе, утичу на дијалошку композицију једног литерарног дела: социјални статус лика, образовни профил лика, општа интелигенција и интелегенција лика у датој ситуацији, његова/њена емоционално-еротска интелигенција, жаргон који употребљава/ју да би га/их боље разумели, узречице и друга језичка помагала, тикови...

Не може, дакле, сваки лик говорити у јавности митопоетског света дела истом врстом језика. Када је то случај у неком делу, онда с правом кажемо да је говор јунака у том делу „књижевни, артифицијелан (вештачки), неутентичан,.. А аутентичност лика, па и целокупног дела, јесте део уверљивости коју покушавамо, као аутори, да градимо од почетка.

Основне функције дијалога су да:

убрза радњу;

1. да читаоцу саопшти чињенице и пренесе му важне информације;

2. да успостави и стабилизује односе међу ликовима;

3. да открије сукобе и емоционална стања ликова;

4. да протумачи радњу;

5. да оцрта карактер лика који говори али и оног лика који слуша и одговара.

Дијалог, пре свега, треба да буде динамизован (брз или успорен у зависности од поетског света који градимо као аутори, или представљамо), треба да подржава све оне карактеристике лика које смо већ навели, треба да сакрије неке од најважнијих ствари које лик има да саопшти себи или другима (а које ће се, дакако, открити касније, током развијања радње), да одражавају свет (миље) у коме се одвија наша приповедана радња.

Све то важи и за романе који су писани у првом лицу (/ch, нем., Ја - романи) - a највећи део стваралачког опуса савремених аутора, од почетка 20. века па до наших дана представљају романи писани у првом лицу -у којима је врста дијалога коју називамо монолог (исповест, дијалог лика са самим собом, дијалог лика са читаоцем) од пресудног приповедалачког значаја. Или, можда, још више значи управо за литерарна дела писана у том кључу. На један начин говори радник на бензинској пумпи другима, саговорницима (а, такође, и са самим собом), на потпуни други доктор наука (а и са самим собом/читаоцем) а на сасвим трећи начин полицајац... Поново подвлачимо да од уверљивости дијалошких или монолошких секвенци зависи и комплетна уверљивост литерарног дела.

А само о реалистичком производу (литерарном делу) креативног писања говоримо у овој студији. Дакле, аутентичност дијалога (или монолога такође) добрим делом гради уверљивост литерарног дела и његову комуникативност са рецепцијентом (читаоцем). 


\section{Креативне способности уметника}

Сваки савременик, читалац и рецепцијент, односно, како се то често колоквијално каже „човек свог доба” схвата да квалитет једног уметничког дела првенствено и, можда, превасходно зависи од креативних способности уметника, од „моћи” самог аутора. Ипак, како не би у овом поглављу студије превише задирали у општу теорију стваралаштва, ограничићемо се на писца, дакле ствараоца литерарног или наративног (приповедалачког) дела.

Оно што уметника разликује од осталих ствараоца (по материјалистичкој теорији друштва) јесу следеће категорије:

1. њега нико не приморава да створи одређено дело већ он сам има потребу да створи такво дело;

2. од квалитета уметничког дела не зависи ништа осим сфере естетике (уколико, за разлику, архитекта и инжењер направе мост лошег квалитета у питању могу бити не само фукционалност већ и људски животи) и односа рецепцијената (читалаца) према аутору;

3. креативне способности уметника су попут већ помињане категорије надахнућа - најмање подложне било каквој дефиницији, односно не постоји мера за одређивање каквоће ове две категорије.

Иначе морамо бити свесни да духовни позив, као професија, престаје да буде део материјалистичке теорије друштва и залази у сферу метафизичког, односно трансцедентног. Другим речима, нису се одређене литерате без разлога инаугурисали као „мајстори, романескног приповедања или приповетке или драмског текста или филмског или телевизијског сценарија.

Код писаца постоји одређена природна припадност, афинитет који их, уколико у стваралачком смислу умеју да ревалоризују (анализирају и потврде или оповргну) своју креативну моћ, дефинише као писце у оквиру једног жанра или медија.

Примера ради, наш чувени комедиограф Бранислав Нушић имао је неколико покушаја да створи трагедију (у ширем смислу те речи) било да је реч о историјског драми („Кнез Иво од Семберије”) или савременој, друштвеној, породично-психолошкој драми („Бура”), али та се дела могу сматрати релативно неуспешним, нарочито уколико имамо у виду његове веома успешне комедије карактера („Ожалошћена породица”, „Др”, „Госпођа министарка”...). Другим речима није сваки жанр или свака медија довољно „податна, једном креативном духу, односно еманацији (метеријализацији) тог духа.

Зато ћемо, не без разлога, приметити да се одређени аутори „специјализују” за одређене жанрове или медија. Из тога произилази закључак да су одређени писци нимало случајно изабрали одређени жанр или медију. Реч је о ауторима који су довољно рационално (објективно) успели да анализирају сопствене креативне моћи и пронађу форму (облик) приповедања у коме су успешнији од: 
1) себе самих (у другим облицима) и успешнији, истовремено;

2) од других аутора у изабраном облику.

Отуда и долази - иначе проблематичан - термин „култног уметника” у одређеној форми (облику) који је (термин) подложан разним мистификацијама али и демистификацијама.

Речју, аутор који је спреман за опсежна историјска или етнографска истраживања (која чине предрадњу његовог стваралаштва) у стању је да напише историјско (односно псеудо-историјски роман); онај кога више интересује чулна интелигенција бића спреман је за стварање управо таквих, интроспективних дела (унутарња анализа сопствених осећања и стања - Маргарет Дирас, Клод Симон, Петер Хандке...); онај коме више лежи дескрипција (описи) бавиће се, најчешће, таквом врстом књижевности... а они којима (нарочито у доба постмодерне) више лежи спекулативна псеудо-историја света (на пример, жанр теорије завере Умберто Еко „Фукоово клатно”, Ден Браун „Да Винчијев код”...), одабраће у изградњи сопственог уметничког опуса управо ту врсту приповедања.

Наравно, треба поменути и оне који суверено владају различитим, међусобно чак и контраидникованим (у поетском смислу) врстама приповедања.

Јохан Волфганг Гете (1749-1832) у својој теорији приповедалаштва говори о три врсте уметника, делећи их на оне који су:

а) представници Простог подражавања - који владају Аристотеловим миметичким приповедањем и могу да „копирају” до потпуног реализма појаве и делања (приче) које региструју око себе;

б) представници Манира - који су способни да верно представљају појаве у свету који их окружује, али им свако дело наликује на претходно јер су усвојили одређени „манир” и не одустају од њега и;

в) представници Стила - који су својим креативним способностима обједињују Просто подражавање, познају ставарачако стање Манира али га избегавају (како им дела не би личила једно на друго, већ увек била оригинална а и препознатљива у одређеној мери). (Gothe, 2006)

Ову поделу Гете даје по квалитативном поретку. Последњи, представници Стила су, дакле, развили сопствени стил и њихова дела бивају препознатљива по стилу али НЕ личе једно на друго. То је, по овом немачком драматичару и теоретичару, врхунац стваралаштва - бити препознатљив али и непоновљив. То, можемо утврдити и дан данас, представља есенцију (срж) оригиналности.

Дакле, већ смо утврдили да одређене теме, сижеи, жанрови или медија више погодују одређеним писцима а мање другима. У простору објективизације сопственог стваралаштва важну улогу игра „самопрепознавање” одређених моћи. У том смислу, можемо да закључимо да разни облици приповедања погодују одређеним писцима док оним другима не. 


\section{Закључак}

Уколико закључимо да су на подручју креативног писања и приповедалаштва уопште, заступљена медија као што су, првенствено, роман, потом прича и приповетка; драма (комедија и трагедија са својим мешовитим врстама); филмски и телевизијски сценарио - односно да они, у тренутку у коме живимо, представљају основне носиоце квалитета приповедања - онда нам постаје потпуно јасно зашто су се неки аутори специјализовали за одређене врсте приповедања.

Роман, причу или приповетку, у данашње време, пишу првенствено они аутори који обраћају посебну пажњу на дескриптивно (описно), идејно и идеолошко, на стања и психологију својих литерарних ликова а нешто мање на њихову делатну активност, на потребу да забележе одређени период цивилизације (најчешће рецентни, актуелни) с његовим прерогативима.

Савремени романописац има, у већем делу своје уметничке трансцеденције, ретроактиван естетски светоназор - он цени и негује причу и сматра да се у причи налазе најважнији прерогативи приповедања. Поменимо неке савремене светске романописце: Халеда Хосеинија („Хиљаду чудесних сунаца”, „Ловац на змајеве”), Амина Малауфа („Саладин”, „Самарканд”), Пера Петешуна („Идемо да крадемо коње”, „Клета реко времена”), Јустејна Гордера („Софијин свет”, „Кћи директора циркуса”), Дена Брауна („Да Винчијев код”, „О анђелима и демонима”), Кристофа Рансмајера („Ужаси леда и мрака”, „Морбус Китихара”), Нила Гејмена („Амерички богови”, „Чаробна прашина”), Салмана Руждија („Сатански стихови”, „Како ме је волела”), Пола Остера („Левијатан”, „Месечева палата”)... - који свој стваралачки гениј (без обзира што смо навели награђиване и ауторе такозваних „блокбастера”, најтиражнијих књига) испољавају готово искључиво на подручју романа.

С друге стране, савремени драмски писац много више пажње обраћа на Аристотеловску категорију делатности својих ликова, на догађаје и брзину (односно ритам и темпо свог приповедања), на дијалог (који је основно средство драмске интерпункције) и дијалошку економију, на дидактичност (поруку или поуку) свог драмског текста, на његову сценичност (приказивачке могућности које собом носи текст чији су аутори), на драмска јединства (ако не буквално на јединство времена и места онда сигурно на јединство радње), на ефектност (литерарно/ сценску „пријемчивост, свог дела), на рефлексивност (приказивање савремене теме у савременом контексту)... Поменимо неке од савремених драмских писаца као што су Роналд Харвуд (драме „Гардеробер”, „На чијој страни”), Мартин Мекдона („Лепотица Линејна”), Дејвид Хер („Небеска светлост”, „Дах живота”), Сара Кејн („Кожа”, „Федрине љубави”, „Психоза 4.48”), Патрик Марбер („Дон Жуан у Сохоу", „Музичари")...

Нешто сасвим друго карактерише писце који су се одлучили за сценаристички посао у филмској и телевизијској (поглавито америчкој и британској) индустрији - спремност на тимски рад, спремност на парцијални (делимичан рад), посебно активан однос према драматуршкој економији, брзини „протока ин- 
формација,, трајању приповедања, посебно флексибилан однос према продуцентима и извршним продуцентима пројекта, свакодневни сценаристички посао када је реч о ТВ серијама, спремност на промене смисла и значења пројекта, спремност за рад на адаптацијама, „измаштавању, наставака серијала и филмова који морају, по поменутој Геотеовској скали, да буду оригинални али и препознатљиви, истовремено... Аутори попут Криса Картера („Досије Икс"), Џона Саливена („Мућке”), Макса Мучника („Вил и Грејс”), Ен Донахју и Ентони Цилкера („Место злочина”), Толкин/Френ Волш („Господар прстенова”)... у свом стваралачком наступу баштине управо поменуте категорије „спремности на посебну врсту приповедалачког рада".

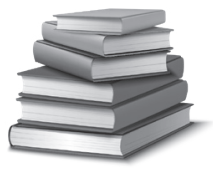

\section{ЛИТЕРАТУРА}

1. Аристотел (1982): Арс Поетика (О песничкој уметности); Београд: Рад.

2. Барт Ролан (1979): Књижевност, митологија, семиологија; Београд: Нолит.

3. Genette, Gerard (1980): Narrative Discourse: An Essay in Method; New York: Cornell University Press.

4. Ginestier Paul (1961): "La geometrie dramatique”, u Le theatre contemporain dans le mond, Paris: Presses universitaires de France.

5. Gothe Johan Volfgang (2006): „Gesprache mit Goethe”, „Conversations of Goethe”; London: Harrison-Ainsworth Press.

6. Derrida Jacques (1985): Letter to A Japanese Friend; Warwick: David Wood\&Robert Bernasconi, Parousia.

7. Јерков Александар (1992): „Постмодерно доба српске прозе”, у Антологија српске прозе постмодерног доба; Београд: СКЗ.

8. Jerkov Aleksandar (1999): Nova tekstualnost, Podgorica: Oktoih.

9. Леви-Строс Клод (1972): Магија и религија; Београд: ИКП Велвет.

10. Леви-Строс Клод (1971): Дивља мисао; Београд: Нолит.

11. Saussure Frederic de (1916): Cours de linguistique générale; Lausanne-Paris: Bally\&Sechehaye.

12. Saussure Frederic de (1977): Course in General Linguistics; Glasgow: Fontana\&Collins.

13. Freytag Gustav; Mac Ewan Elias J. (2000): Drama-Technique; Chicago: ScottForesman Press.

14. Fry Northrope (2006): The Grat Code - The Bible and literature; Toronto: University of Toronto Press.

15. Шион Мишел (1989): Написати сценарио; Београд: Научна књига/Институт за филм. 


\section{Miomir PETROVIĆ}

\section{THEORY OF FREYTAG'S}
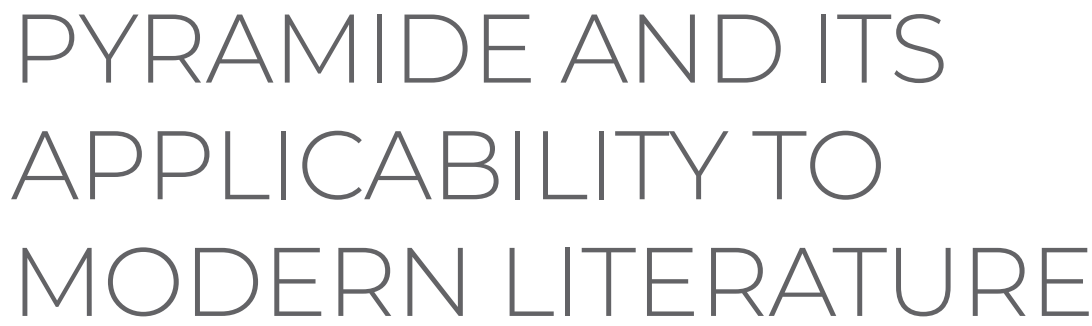

Abstract: Since the beginings, the theater has been often used for expressions of philosophical thought in the form of direct dialog. With theatrical positions it must be concluded that the theater often plays a part stands for para-theater operations and assigned to the limit when it became unclear whether this is a theater in general. However, the debate "for" or "against" engaged theater looks today more than out of place, since both have a clear opinion confirming the history of theater. If we look at the numerous theories of drama from a wider perspective, the perspective of the media, we immediately see that the theater aesthetics rests on the principles of mass communication, collective perceptions, interactions of the world scene and world audience and evoking event theater professionals cannot speak and not to talk, simultaniosly, about the world, society, the collective. It is clear that the dramatic literature has directly or indirectly involved, the nature of its invoices and creative means of expression.

Keywords: CREATIVE WRITING, THEATER, MYTH, DRAMA, CHARACTER, DIALOGUE, ANTAGONISM, PROTAGONIST. 